\title{
Changing Temperature and Rainfall Patterns of Uttarakhand
}

\author{
Ashutosh Mishra* \\ Geography Department, University of Allahabad, India
}

Submission: December 08, 2017; Published: December 15, 2017

*Corresponding author: Ashutosh Mishra, Senior Research Fellow, Geography Department, University of Allahabad, Allahabad-211005, U.P, India, Tel: +91-9415866666; Email: ashutoshkmisra@gmail.com

\begin{abstract}
Nested in the lap of mighty Himalayas, the Indian state of Uttarakhand is climatologically very sensitive and ecologically fragile. Owing to its natural beauty, religious tone and rich biological succession the state is known as 'Land of Gods' and 'land of austerity.' However, increasing population pressure is posing a great challenge to the natural harmony of this vulnerable state. During recent years the state has recorded a significant increase in climatological disasters and for that the humanogenic enhancement of regional atmospheric entropy is being seen as the cause. Present paper analyses temperature and rainfall changes that the state has witnessed during the last century. The study is mainly based on the district temperature and rainfall series of 102 years obtained from India Meteorological Department. The analysis reveals that the state has recorded a significant increase in temperature while the volume of rainfall it receives annually, has declined during the course of the last century. The monthly changes show that the state is losing its seasonal contrast, and while winter months are becoming warmer, monsoon months are losing their heat and also the quantum of rainfall.
\end{abstract}

Keywords: Chaotic; External Perturbation; Humanogenic; Self Balancing System; Climatological Disasters

\section{Introduction}

Uttarakhand, one of the 12 Himalayan states of India, is known for its natural beauty and highly varied physiography. Its snow-clad peaks, beautiful hill stations, extended duns and rich biological succession makes it a favourite destination for tourists. About 83 percent land of the state lies under hills while most of the population of the state lives in the southern narrow belt of Tarai plains. Uttarakhand is considered to be highly sensitive for climate related changes due to its varying topography and rich glacier mass. Intensifying human activities like deforestation, urbanisation, mining etc, may affect the regional climo-balance adversely and, thus, may change the pace and fate of the ongoing geomorphic processes [1]. Although climate is a self-balancing robust system that is capable to manage small (humanogenic) changes however, due to its chaotic nature it goes random at some stage in course of its management cycle.

This random state speaks about the unexpected shifts in the climate. Such big shifts which are nothing but the accumulation of small changes often result into a catastrophe. Keeping in mind this chaotic nature of climate system, it is, therefore, necessary to monitor every pulse of climate, if our existence really matters [2,3]. The state of Uttarakhand, which has witnessed a notable increase in climatologically disasters during recent years, highlights the need of a precise estimation of changes that are taking place in climate. Present paper is an attempt in the direction where it examines the variability profile of temperature and rainfall of Uttarakhand to discern the emerging trends.

\section{Data Source and Methodology}

The study analyses a 102-year (1911-2012) temperature and rainfall data of Uttarakhand obtained from IMD, Pune and India water portal. The changes at annual and monthly scales were identified by regressing analysis. The anomalies were computed from an averaged values of a 30 years' reference period (19611990).The two major considerations for favouring this base periodic: the observational climate data coverage and availability are better for this period as compared to earlier ones; and, the years after 1990 are likely to have larger anthropogenic trends embedded in the climate data owing to the intensified human activities following the 1990s economic reforms.

\section{Temperature Changes}

Temperature is the key factor that determines climatic properties of a place. The distribution of temperature condition over Uttarakhand varies greatly from $-1.7^{\circ} \mathrm{C}$ at Mukteswar to $42^{\circ} \mathrm{C}$ at Pantnagar. This large variation conveys state`s sensitivity for climate change. Fig. 1 demonstrates temperature variability over Uttarakhand during last century. In all the course of temperature profile, a 4-5 year normal cyclist is quite evident, however, but as far as trend is concerned, no significant change was recorded till 1950. However, after this, the temperature started rising, but 1970 onwards it started declining. Nevertheless, the rising trend resumed after 1990 and is continued till present. Amid these fluctuating phases, the state, however, registered $0.46^{\circ} \mathrm{C}$ increase in mean annual temperature during the last century. 
a) Table 1 shows the changes in temperature at district level. Evidently all the 13 districts of the state have recorded a notable increase in temperature.

b) Figures $1 \& 2$ showing the spatial distribution of warming over the state clearly demonstrates that the hill regions are warming more prominently than the plains like Hardwar which is entirely a plain district, is at the lowest rung in the warming table.

Table 1: Annual Mean Temperature Changes in Uttarakhand.

\begin{tabular}{|c|c|c|c|}
\hline $\begin{array}{c}\text { Districts Where Temperature is } \\
\text { Increasing Significantly at 99\% }\end{array}$ & $\begin{array}{c}\text { Annual Mean Temperature } \\
\text { Trend in }{ }^{\circ} \mathbf{C} \mathbf{1 0 0} \text { Years }\end{array}$ & $\begin{array}{c}\text { Districts Where Temperature is } \\
\text { Increasing Significantly at 95\% }\end{array}$ & $\begin{array}{c}\text { Annual Mean Temperature } \\
\text { Trend in }{ }^{\circ} \mathbf{C} \mathbf{1 0 0} \text { Years }\end{array}$ \\
\hline Pithoragarh & 0.58 & Garhwal & 0.41 \\
\hline Chamoli & 0.54 & Dehradun & 0.37 \\
\hline Rudraprayag & 0.53 & Hardwar & 0.34 \\
\hline Bageshwar & 0.52 & & \\
\hline Uttarkashi & 0.51 & & \\
\hline Champawat & 0.49 & & \\
\hline Almora & 0.46 & & \\
\hline Nainital & 0.44 & & \\
\hline Tehri Garhwal & 0.43 & & \\
\hline Udham Singh Nagar & 0.42 & & \\
\hline
\end{tabular}

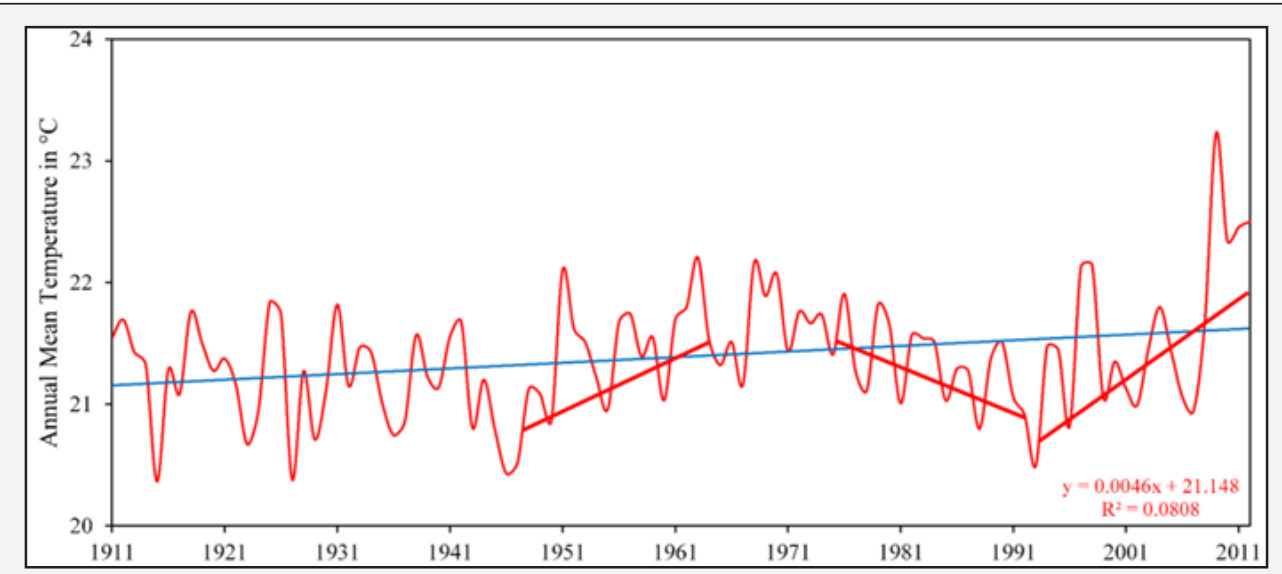

Figure 1 : Annual Mean Temperature Trend of Uttarakhand (1911-2012).

Table 2: Monthly Mean Temperature Changes $\left({ }^{\circ} \mathrm{C} / 100\right.$ Year).

\begin{tabular}{|c|c|c|c|c|c|c|c|c|c|c|c|c|}
\hline District/State & Jan & Feb & Mar & Apr & May & Jun & Jul & Aug & Sep & Oct & Nov & Dec \\
\hline Almora & 0.49 & $1.77^{* *}$ & 1.12 & 0.75 & 0.09 & -0.43 & -0.27 & $-0.36^{*}$ & -0.21 & 0.29 & $1.00^{* *}$ & $1.27^{* *}$ \\
\hline Bageshwar & 0.63 & $1.79^{* *}$ & 1.19 & 0.80 & 0.14 & -0.36 & -0.20 & -0.31 & -0.18 & 0.35 & $1.01^{* *}$ & $1.32^{* *}$ \\
\hline Chamoli & 0.73 & $1.73^{* *}$ & $1.25^{*}$ & 0.87 & 0.23 & -0.27 & -0.22 & -0.24 & -0.17 & 0.37 & $1.00^{* *}$ & $1.24^{* *}$ \\
\hline Champawat & 0.54 & $1.77^{* *}$ & 1.07 & 0.71 & 0.14 & -0.38 & -0.17 & -0.31 & -0.18 & 0.33 & $0.99^{* *}$ & $1.32^{* *}$ \\
\hline Dehradun & 0.56 & $1.47^{* *}$ & $1.07^{*}$ & $1.15^{*}$ & 0.46 & -0.50 & $-0.58^{*}$ & $-0.50^{*}$ & $-0.44^{*}$ & -0.09 & $0.87^{* *}$ & $0.97^{* *}$ \\
\hline Garhwal & 0.54 & $1.63^{* *}$ & 1.05 & 0.92 & 0.21 & -0.47 & -0.45 & $-0.43^{*}$ & -0.33 & 0.16 & $0.93^{* *}$ & $1.14^{* *}$ \\
\hline Hardwar & 0.55 & $1.50^{* *}$ & 0.90 & $1.12^{*}$ & 0.30 & -0.55 & $-0.63^{*}$ & $-0.51^{*}$ & $-0.48^{*}$ & -0.07 & $0.87^{* *}$ & $1.11^{* *}$ \\
\hline Nainital & 0.44 & $1.75^{* *}$ & 1.03 & 0.72 & 0.06 & -0.49 & -0.29 & $-0.35^{*}$ & -0.24 & 0.28 & $1.05^{* *}$ & $1.32^{* *}$ \\
\hline Pithoragarh & 0.78 & $1.82^{* *}$ & $1.24^{*}$ & 0.87 & 0.21 & -0.26 & -0.10 & -0.25 & -0.13 & 0.39 & $1.02^{* *}$ & $1.36^{* *}$ \\
\hline Rudraprayag & 0.72 & $1.71^{* *}$ & $1.23^{*}$ & 0.89 & 0.28 & -0.27 & -0.28 & -0.24 & -0.20 & 0.34 & $0.98^{* *}$ & $1.16^{* *}$ \\
\hline
\end{tabular}




\section{International Journal of Environmental Sciences \& Natural Resources}

\begin{tabular}{|c|c|c|c|c|c|c|c|c|c|c|c|c|}
\hline Tehri Garhwal & 0.60 & $1.54^{* *}$ & $1.16^{*}$ & 1.01 & 0.36 & -0.40 & -0.42 & -0.38 & -0.31 & 0.13 & $0.90^{* *}$ & $0.99^{* *}$ \\
\hline Udham Singh Nagar & 0.44 & $1.70^{* *}$ & 0.99 & 0.76 & 0.08 & -0.57 & -0.36 & $-0.35^{*}$ & -0.30 & 0.27 & $1.10^{* *}$ & $1.31^{* *}$ \\
\hline Uttarkashi & 0.67 & $1.58^{* *}$ & $1.29^{*}$ & $1.02^{*}$ & 0.46 & -0.28 & -0.33 & -0.27 & -0.22 & 0.20 & $0.98^{* *}$ & $1.06^{* *}$ \\
\hline Uttarakhand & 0.59 & $1.67^{* *}$ & 1.12 & 0.89 & 0.23 & -0.40 & -0.33 & $-0.35^{*}$ & -0.26 & 0.23 & $0.98^{* *}$ & $1.20^{* *}$ \\
\hline
\end{tabular}

**. Trend is significant at $99 \%$ confidence level.

*. Trend is significant at $95 \%$ confidence level.

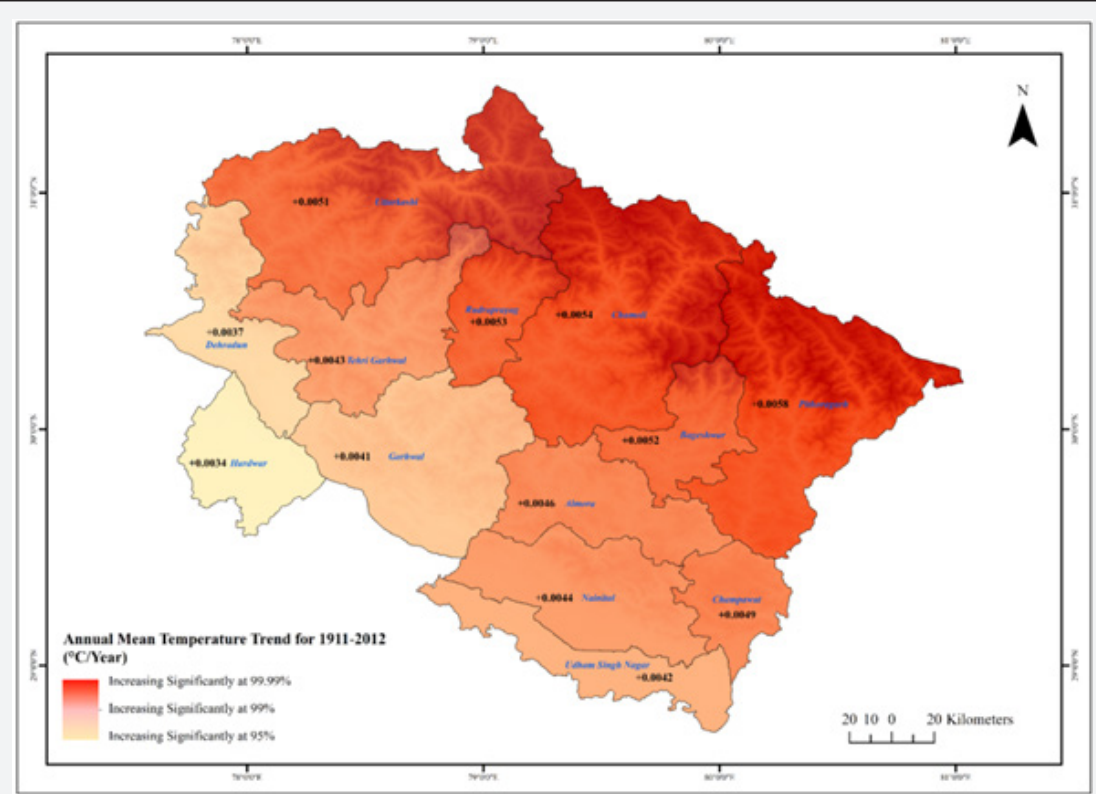

Figure 2 : Annual Mean Temperature Changes.

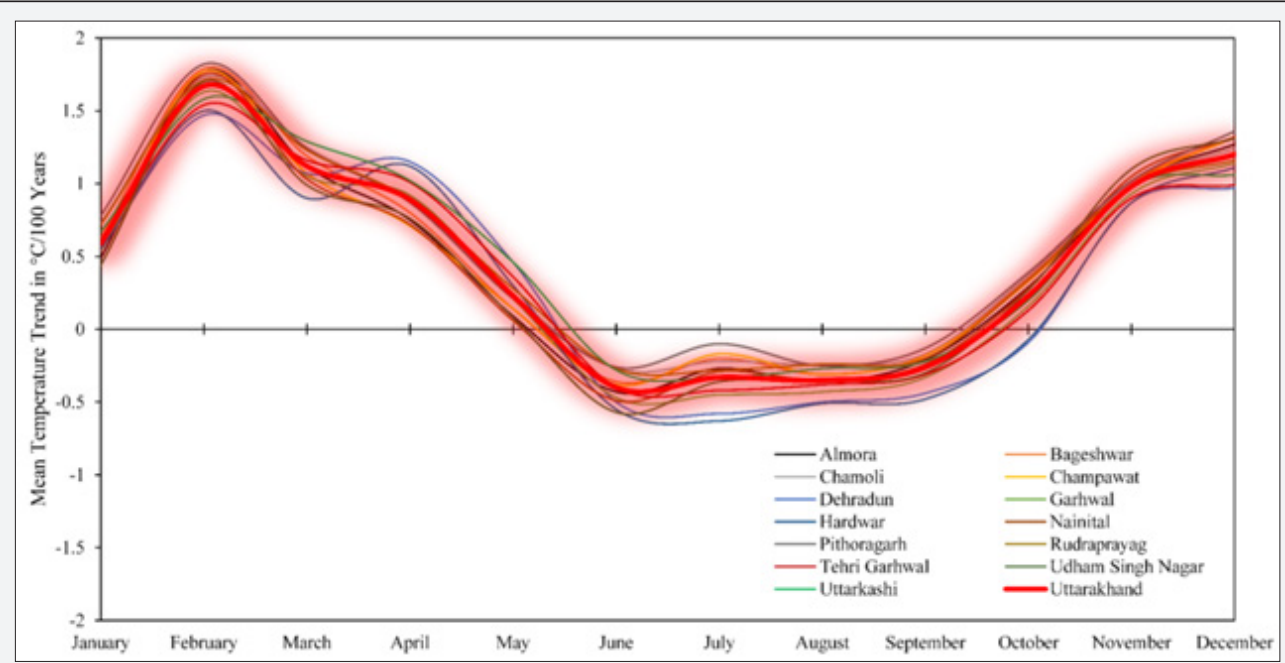

Figure 3 : Monthly Mean Temperature Changes.

\section{Rainfall Changes}

Rainfall is the most critical element of climate that determines the nature of life at a place Figure 4 shows the pattern of rainfall in Uttarakhand during 1911-2012. The fluctuation in quantum of rainfall is quite evident, however, the slope of trend line suggests a declining trend that has become more prominent after 1990, and on an average the state has recorded a rainfall deficit of $13.05 \mathrm{~cm}$. (insignificant although) in last 100 years. The changes in annual rainfall at the district level during last century have been shown in Table 3. It is noteworthy that besides Hardwar, which has witnessed a slight increase, all the districts are in rainfall deficit, Figure 5 shows the spatial distribution of these changes. It is quite 
revealing that the hill regions of the state are becoming drier while the rainfall is declining from south to north and from west to east. The monthly changes in the rainfall has been summarised in Table 4. It is noteworthy that except the months of March, May and November, other months are rainfall deficient Figure 6 displays the monthly changes more clearly. It is quite evident that the volume of rain during monsoon season (June-September) is declining. This change is quite alarming. It may impact the crop yield adversely.

Table 3: Changes in Annual Rainfall.

\begin{tabular}{|c|c|c|c|c|c|}
\hline $\begin{array}{c}\text { District Witnessing } \\
\text { Increasing Rainfall }\end{array}$ & $\begin{array}{c}\text { Trend of Annual } \\
\text { Rainfall in } \\
\mathbf{c m} . / \mathbf{1 0 0 Y e a r s}\end{array}$ & $\begin{array}{c}\text { District Witnessing } \\
\text { Decreasing Rainfall }\end{array}$ & $\begin{array}{c}\text { Trend of Annual } \\
\text { Rainfall in } \\
\mathbf{c m} . / \mathbf{1 0 0 Y e a r s}\end{array}$ & $\begin{array}{c}\text { District Where } \\
\text { Rainfall is } \\
\text { Decreasing } \\
\text { Significantly at 95\% }\end{array}$ & $\begin{array}{c}\text { Trend of Annual } \\
\text { Rainfall in } \\
\mathbf{c m} \text { /100Years }\end{array}$ \\
\hline Hardwar & 1.37 & Chamoli & 15.30 & Champawat & 24.22 \\
\hline & & Udham Singh Nagar & 12.97 & Pithoragarh & 21.16 \\
\hline & & Rudraprayag & 12.48 & Bageshwar & 19.01 \\
\hline & & Garhwal & 9.25 & Almora & 17.60 \\
\hline & & Tehri Garhwal & 8.53 & Nainital & \\
\hline
\end{tabular}

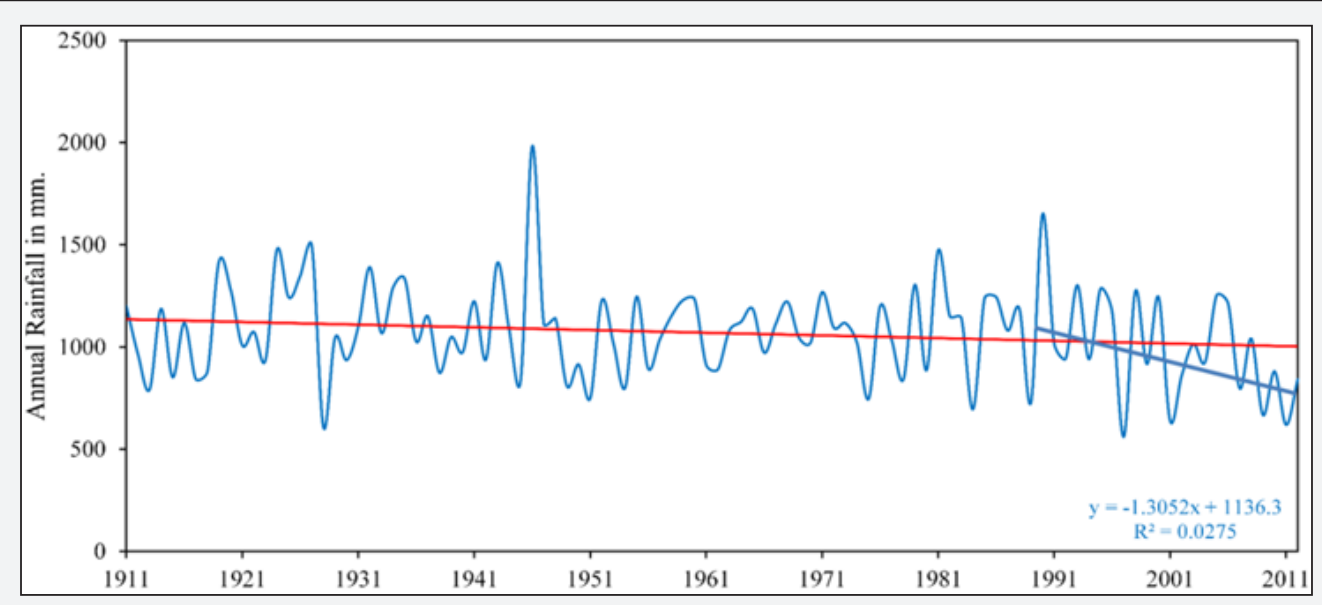

Figure 4 : Annual Rainfall Trend of Uttarakhand.

Table 4: Monthly Rainfall Changes (cm/100 Year).

\begin{tabular}{|c|c|c|c|c|c|c|c|c|c|c|c|c|}
\hline District/State & Jan & Feb & Mar & Apr & May & Jun & Jul & Aug & Sep & Oct & Nov & Dec \\
\hline Almora & -0.85 & -0.31 & 0.66 & -0.10 & 1.10 & -3.29 & -5.39 & -7.95 & -1.68 & -1.00 & -0.02 & -0.19 \\
\hline Bageshwar & -0.95 & -0.44 & 0.82 & -0.23 & 1.28 & -3.75 & -5.31 & $-8.16^{*}$ & -2.33 & -1.36 & -0.03 & -0.21 \\
\hline Chamoli & -0.88 & -0.30 & 0.91 & -0.27 & 1.17 & -2.43 & -3.40 & -6.58 & -2.27 & -1.00 & -0.04 & -2.17 \\
\hline Champawat & -0.52 & -0.42 & 0.53 & -0.06 & 1.11 & -5.36 & -7.03 & $-9.12^{*}$ & -1.96 & -1.39 & 0.03 & -0.04 \\
\hline Dehradun & -0.80 & 0.19 & 0.71 & 0.14 & 0.80 & -0.41 & 0.07 & -2.17 & -0.55 & -0.01 & 0.05 & -0.35 \\
\hline Garhwal & -0.75 & -0.10 & 0.62 & -0.07 & 0.98 & -1.57 & -2.38 & -4.61 & -0.71 & -0.44 & 0.00 & -0.22 \\
\hline Hardwar & -0.57 & 0.01 & 0.51 & 0.08 & $0.94^{*}$ & -0.10 & 1.32 & -0.32 & -0.39 & 0.05 & 0.06 & -0.22 \\
\hline Nainital & -0.62 & -0.33 & 0.52 & -0.02 & 1.01 & -3.05 & -5.30 & -7.49 & -1.38 & -0.83 & 0.01 & -0.11 \\
\hline Pithoragarh & -0.91 & -0.52 & 0.92 & -0.40 & 1.28 & -4.20 & -5.47 & $-7.36^{*}$ & -2.63 & -1.67 & -0.01 & -0.20 \\
\hline Rudraprayag & -0.86 & -0.07 & 0.90 & -0.13 & 1.04 & -1.79 & -2.96 & -5.79 & -1.91 & -0.73 & 0.00 & -0.19 \\
\hline Tehri Garhwal & -0.85 & 0.16 & 0.77 & 0.09 & 0.87 & -1.11 & -2.65 & -4.25 & -1.06 & -0.28 & 0.03 & -0.25 \\
\hline Udham Singh Nagar & -0.49 & -0.30 & 0.42 & 0.02 & $1.03^{*}$ & -2.13 & -4.41 & -5.66 & -0.84 & -0.55 & 0.03 & -0.08 \\
\hline Uttarkashi & -0.78 & 0.29 & 0.96 & 0.18 & 0.86 & -0.80 & -2.13 & -4.12 & -1.61 & -0.26 & 0.04 & -0.20 \\
\hline Uttarakhand & -0.76 & -0.17 & 0.71 & -0.06 & 1.04 & -2.31 & -3.46 & -5.66 & -1.49 & -0.73 & 0.01 & -0.19 \\
\hline
\end{tabular}




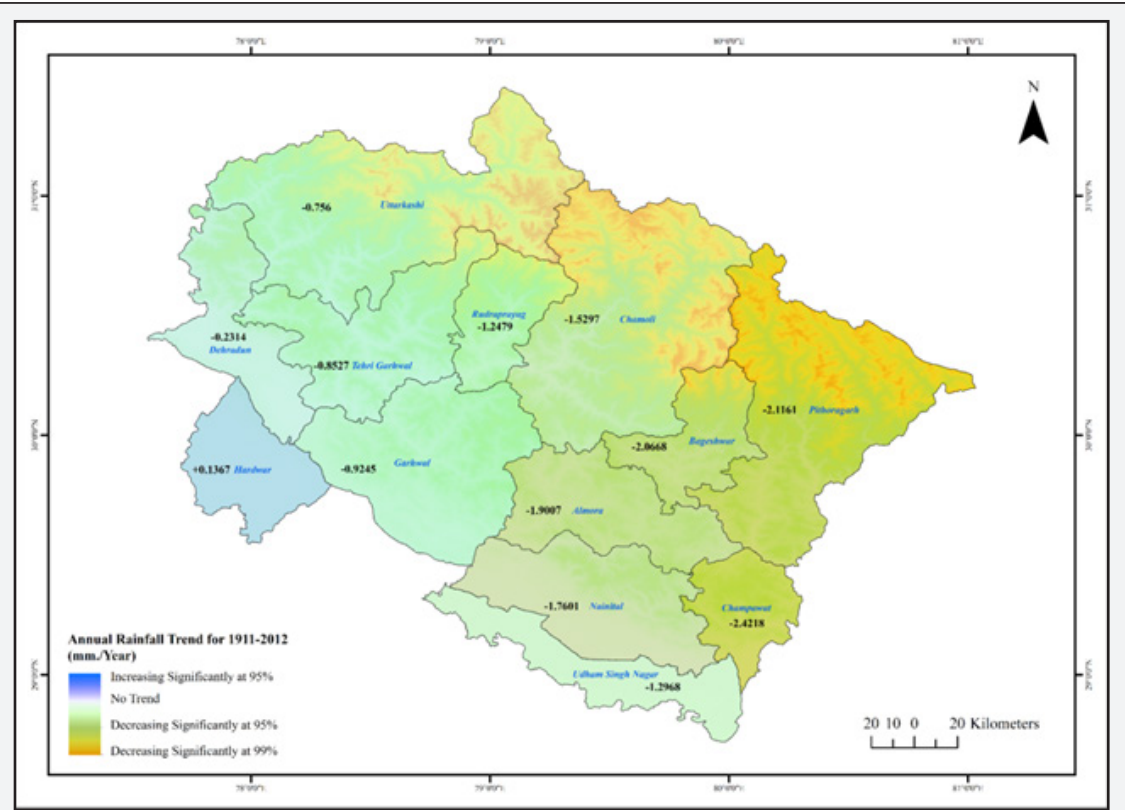

Figure 5 : Annual Rainfall Changes in Uttarakhand.

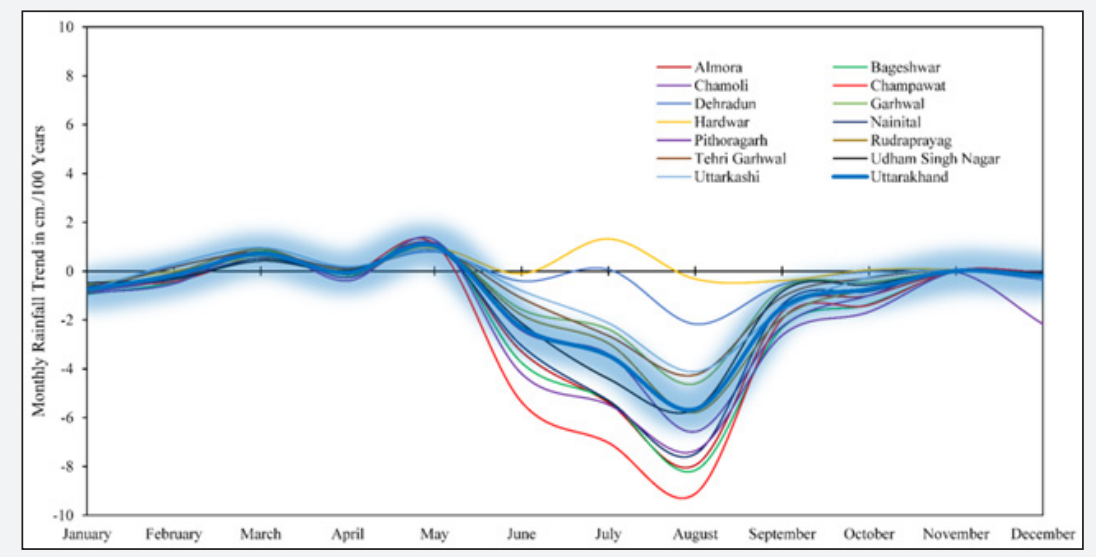

Figure 6 :Monthly Rainfall Changes.

\section{Conclusion}

The analysis reveals that the state of Uttarakhand is experiencing a significant warming and the temperature in hilly areas is rising more prominently than the plains. The month wise temperature trend analysis, however, show that the state is losing its seasonal contrast as winters are becoming warmer and the rainy season is missing its heat. The decrease in rainfall and especially during rainy months- June-September, indicate that climate of the state is changing notably. Although, the pangs of climatic change may not be visible at this stage, but the scenario, that is emerging, warns that these changes may alter the regional energy balance and, thus, may change the pace of ongoing geomorphologic processes. Undoubtedly this will impact the physical, social as well as cultural settings of the state.

\section{References}

1. Cruz RV, Harasawa H, Lal M, Wu S, Anokhin Y, et al. (2007) Asia. In:Climate Change 2007: Impacts, Adaptation and Vulnerability. Contribution of Working Group II to the Fourth Assessment Report of the Intergovernmental Panel on Climate Change, ML Parry, OF Canziani, JP Palutikof, PJ Linden VD, and Hanson, C.E. (Eds.) Cambridge University, Press Cambridge, UK, pp. 469-506.

2. GSI (2001) Glaciology of the Indian Himalaya. GSI Special Publication No. 63, Geological Survey of India.

3. Raina VK (2009) Himalayan Glaciers: A State-of-Art Review of Glacial Studies, Glacial Retreat and Climate Change. MOEF Discussion Paper, Ministry of Environment \& Forests, Government of India, p. 1-56. 
(C) (D) Commons Attribution 4 This work icentive BY DOI: 10.19080/IJESNR.2017.07.555716
Your next submission with Juniper Publishers will reach you the below assets

- Quality Editorial service

- Swift Peer Review

- Reprints availability

- E-prints Service

- Manuscript Podcast for convenient understanding

- Global attainment for your research

- Manuscript accessibility in different formats

( Pdf, E-pub, Full Text, Audio)

- Unceasing customer service

Track the below URL for one-step submission https://juniperpublishers.com/online-submission.php 